\title{
French Learners' Opinion About the Effect of Study Abroad Experience on Language Learning
}

\author{
Canan Aydınbek ${ }^{1 *}$
}

\author{
${ }^{1}$ Anadolu University, Faculty of Education, French Language Teaching Department, Eskişehir 26470, TURKEY \\ *Corresponding Author: caydinbek@anadolu.edu.tr
}

Citation: Aydınbek, C. (2019). French Learners' Opinion About the Effect of Study Abroad Experience on Language Learning. Mediterranean Journal of Social \& Behavioral Research, 3(2), 25-28. https://doi.org/10.30935/mjosbr/9590

Note: This article was presented in ICOINE 2014 : 3rd International Conference on Interdisciplinary Research in Education, 29-31 October 2014, Milano, Italy.

\begin{abstract}
According to the majority of learners and educators, the best way to learn a second language is to live in a country where this language is spoken. To become proficient in a second language, study abroad is admitted as 'sine qua non'. Several studies demonstrated the positive impact of the study abroad experience. However, they usually measured language gains by test scores. Fewer studies consider the value of learners' view of their personal and linguistic development during study abroad.

The aim of this study is to enlighten the perceptions of French learners study abroad experience and how a L2 is learned. We used semi-structured interview for collecting data from six students of French Language Teaching Department at Anadolu University. The subjects stayed in France during 2012-2013 academic year, one or two semesters with Erasmus exchange program. Students reported that they have gained fluency and their selfconfidence has developed after the experience.
\end{abstract}

Keywords: study abroad experience, language learning, proficiency, fluency

Received: 15 Feb. $2019 \bullet$ Revised: 14 Jun. 2019 • Accepted: 02 Jul. 2019

\section{INTRODUCTION}

According to a common belief in the field of foreign language learning, the most effective way of learning a language is to live in a country where the language is spoken. During the period spent abroad, the learners are exposed to a large amount of authentic language input, especially the oral skills improve through interaction with native speakers. The results of numerous studies and experiences have proven that this belief is true to a large extent. One of them, carried out by John Carrol (1967) with 2,782 college seniors majoring in French, German, Italian and Russian demonstrated that the students who spent time abroad tend to acquire greater proficiency in the second language than those who studied at home.

The study of Willis and his colleagues cited in Freed (1998), has also supported the linguistic growth (measured by scores) of 88 British students who spent abroad more than a year (Willis, Doble, Sankarayya and Smithers, 1977). Similar studies pointed to the linguistic advantages of a period spent abroad: Dyson (1988), Veguez (1984), Magnan (1986), Foltz (1991), Meara (1994), Coleman (1996), (Freed, 1998, p.5).

The study of Brecht, Davidson and Ginsberg $(1991,1995)$ and that of Lapkin et al. (1995) considered both student's prior learning experience in order to predict success abroad. Despite different student populations and target languages (Brecht et al. studied with American students studying Russian and Lapkin et al. with Canadian adolescents who have participated in a bilingual interprovincial exchange program) two studies have shown certain similarities.

A series of research (Lafford, 1995; Freed, 1995b; Huebner; 1995, Milleret, 1991) have compared language skills acquired in classroom context and during study abroad period (Freed, 1998). These studies have provided a description of some specific linguistic features as fluency and accuracy which differ in the language of two compared student groups. Despite individual variations pointed out in different studies, according to Tanaka, Ellis (2003),

on the whole, an increase in natural exposure to the $\mathrm{L} 2$ through a study-abroad experience seems to contribute more to fluency and naturalness of speech (i.e., higher speech rate and fewer disfluent, silent pauses) than to accuracy and complexity of speech. Compared with gains in fluency and naturalness of speech, the improvement in grammar, listening, and reading is relatively low. 
However, the extent to which the language is learned and witch aspects of second language have improved depends on numerous variables. These variables include individual differences in motivation, aptitude, learning styles, age, level of pre-program language proficiency, the features of the language to be learned, the length of time spent abroad, homestay placements, whether the students have received formal classroom instruction and the degree to which they are immersed in the second language community, in other words, the frequency of their contact with the native speakers. Consequently, it is certain that a period spent abroad accelerate at a large extent language learning process. Nevertheless, a research should not only state the linguistic growth of students but also it should specify the conditions in which the maximum linguistic development may occur.

\section{Contribution of Qualitative Studies}

A series of qualitative studies enhance the research of study abroad by offering a view from the perspective of the students who participate in these programs. These investigations emphasized multiple individual factors that play an immense role in study abroad experience. (Klein, 1993; Pellegrino, 1997; Siegal, 1995) Such as the investigation of Wilkinson that focused on participant's backgrounds and expectations (Wilkinson, 1998). "The texture and richness of students' perceptions of the study abroad experience provide tremendous insights into the benefits and costs of in-country language study in terms of linguistic development, cultural understanding, and personal growth" (Pellegrino, 1998, p.114). Despite the apparent scientific limitations of qualitative methods, they allow pedagogues and administrators to anticipate student's difficulties encountered abroad in order to enhance the positive effect of study abroad experience. These findings are also of great benefit to students who are preparing to go abroad and to researchers who need to discover student's personal experience from their own perspective. In addition, student's thoughts on their own experience and how they conceive language learning process may give some ideas for best organization of formal instruction setting.

It is clear that the classroom context is different from study abroad setting in many respects. First of all, formal instruction is more focused to accuracy and grammar than fluency and communication. Whereas in study abroad context achieving a communicative goal and spontaneity are more important than accuracy. This is why the students mostly tend to produce correct sentences without knowing in which communication situation they should be used. As a result, the fear of making mistakes prevent the natural speech of students.

As pointed out by Pellegrino (1998, p.97),

according to the classroom-based view, meaning that 'successful L2 use is measured by correct grammatical form and target expressions, rather than achievement of the communicative goal. Thus, if learners fear failure and perceive grammatical mistakes as negative and experimental phraseology as leading to potentially incorrect L2 usage, they may reject opportunities to experiment if they believe they are unable to do so accurately.

One of the various advantages of study abroad experience is that the frequent contact with native speakers allows students to get rid of the fear mentioned above. Consequently, at the end of a period spent abroad students feel more fluent and as a result more self-confident.

\section{METHODS AND PROCEDURES}

\section{Research Questions}

The main objective of this work is to understand students' perspective on their study abroad experience and to reveal the changes in their beliefs on the L2 learning process. Thus, the following questions were addressed in this study:

1. Was the period spent abroad sufficient to improve students' French level?

2. What changes in the learners' French language proficiency occurred during the study-abroad program?

3. What changes in the learners' beliefs about language learning process occurred during the study-abroad program?

4. What type of communicative difficulties students encountered in the classroom and out of the classroom during study abroad period?

5. Did students have problems due to cultural differences between their own culture and the target culture?

6. According to students what is the most efficient way to learn a L2?

\section{Participants}

Six undergraduate student studying in French Language Teaching Program have participated in this study. They study French for 2 or 3 years and they learn French in the preparatory class during an academic year, after having studied English in high school. None of them have been abroad before this program except one who have been in France before for 3 months. They are supposed to be at level B2 before participating to the exchange program. They spent one or two semester in France. Three of them have spent 4 months, two have spent 9 months and one 11 months.

\section{Instruments and Data Analysis}

In this study we used semi-structured interview as a qualitative data collection tool. Participants were asked to answer to 13 questions which 7 were closed-ended, 6 were open-ended regarding their period spent in France, their experiences, and opinions on language learning process. Interviews were one-on-one, lasted approximately ten minutes, and were audio-taped and transcribed. The interviews were conducted in Turkish, the data was transcribed and then translated to English. Than it has read and coded by the researcher and another colleague in order to identify the important concepts. As says Maxwell, "simply reading the notes or transcripts is an important step in the analytic process. Researchers should make frequent notes in the margins to identify important statements and to propose ways of coding the data..." (Maxwell, 1996, p.6).

\section{RESULTS}

The table below indicates the important statements as well as words used by students during the interview. According to the answers of the first and second questions, the students who have spent 3 months think that this period is not enough to improve L2. The first student precise that it depends on what you do abroad. That means, on condition that take advantage of frequent contact with native speakers, 3 moths may be sufficient. The students who have spent 9 and 11 months in France think that this period is absolutely sufficient. Because during first weeks 
Table 1. Comparison between Study Abroad Settings and the Classroom Context (at Home)

\begin{tabular}{ll}
\hline Study Abroad Setting & Instructional Learning Context \\
\hline $\begin{array}{l}\text { Oral skills, speaking, fluent, vocabulary, pronunciation, accent, to } \\
\text { express herself easily, spontaneous, improvised }\end{array}$ & $\begin{array}{l}\text { Accuracy, focus on writing, grammatical point of view, no fluent, lack } \\
\text { of automatism }\end{array}$ \\
\hline Street French, daily French & Language of the books \\
\hline To learn what to say where and how, to experience the L.2 & Things abstract, non-correlation, things in air \\
\hline $\begin{array}{l}\text { To practice, to hear, to see and to learn visually } \\
\text { To be exposed to L.2 }\end{array}$ & To memorise \\
\hline Self-confidence, to get rid of shyness, to correct errors & Fear of making errors, anxiousness, timidity \\
\hline To be forced to speak all the time, to speak French everywhere & To speak French only in the classroom \\
\hline To learn language and culture together & Focus on language rather than culture \\
\hline
\end{tabular}

and first semester they try to accustom to new conditions. The third question was about the differences in students' French level before and after the study abroad experience and the sixth question is in correlation with it, asking which language skill has most developed after the stay abroad. The answers to two questions permit to compare study abroad setting and instructional language learning context. The comparison based on students' own expressions are illustrated in Table 1.

We can summarise the findings as follows:

- Instructional teaching is focused on grammar, writing, and accuracy rather than achieving communicative goals.

- There are some differences between the French taught in the classroom namely the textbook's French and that spoken by native speakers.

- In the classroom, students learn about the language but they don't learn enough how and when to use them. In other words, they can't associate the correct sentences with the communication situation in which they are supposed to be used.

- In study abroad setting, students learn by experiencing, practicing and solving real communicative problems. Or, in the classroom they usually tend to memorise knowledge.

- During study abroad period, students get rid of the fear of making errors and as a result they feel more self-confident.

- Learning a L.2 at home, in the classroom, is limited to a few hours per day or per week and out of the classroom students don't have any chance to practice the L.2. However, a stay in country allows students to use the L.2 anywhere and anytime. That is to say, they are totally immersed in the community speaking French.

- A stay abroad offers many opportunities for understanding and learning the target culture better than the classroom context does.

- The students have encountered communication problems outside of the classroom and they used dictionary and gestures to solve them. In the classroom, some of them had difficulties due to vocabulary. But the courses there were similar to the courses they fallow in Turkey. Thus they didn't have big problems.

- The students attested that they didn't have difficulties sourced by cultural differences and that there isn't big differences between their own culture and the target culture. Except two students who had problem with foods and strange smell.
- They all think that the oral skills have most developed during the period spent abroad, one of them specified that his reading skills have also improved.

- Oral communication course that they fallowed before study abroad was very useful for their study abroad experience. One student says that writing course was also useful because she learn better by writing.

- According to students the best way to learn a language is to stay in a country where this language is spoken. But they pointed out the importance of oral communication and contacting native speakers. They recommend to use films, radio and television programs, songs, poems and Internet in self learning as well as in the classroom in order to develop linguistic skills.

\section{CONCLUSION}

It is certain that one of the most effective ways to learn a L2 is to stay and study in a country where this language is spoken. Because, this period allows learners to practice the knowledge that they have learned in the classroom. In their home country, they don't have to use the L2 out of the classroom. Thus, they aren't usually aware of the language level they reached. Test scores and institutional exams are not sufficient to measure competence of communication. That's why they need a guidance to progress on their way. Students said that the language of the books is different from the spoken language. In order to minimize this difference, the teachers and instructors should first use more frequently authentic materials. They should also guide the students in self-learning and encourage them to use L2 out of the classroom. If the teachers try to enrich the content of L2 course with movies, songs, poems and websites, the learners could learn how and where to access to L2 as it's used by native speakers. Secondly, the classroom activities tend to focus on grammar and writing, rather than communication. Then, teachers should prefer a teaching approach that prioritizes communication instead of accuracy. Thirdly, the teaching context of the classroom should be arranged to prepare students out of classroom communication situations, especially before a stay abroad, they should be aware of difficulties that they could probably encounter during the time spent abroad.

Finally, the individual needs of students such as learning styles, motivation, and use of communication strategies should be taken into account. To some students who have difficulty in expressing himself, speaking exercises can be planed. Therefore, students who realize that they are able to communicate in L2, gain self-confidence and their motivation level increases. As said by a student "the more you speak the 
more you are motivated and the more you are motivated the more you speak".

\section{REFERENCES}

Amuzie, G. L., \& Winke, P. (2009). Changes in language learning beliefs as a result of study abroad. System, 37, 366-379. https://doi.org/10.1016/j.system.2009.02.011

Freed, B. (1995). What makes us think that students who study abroad become fluent? In B. F. Freed (ed.), Second Language Acquisition in a Study Abroad Context, 123-148. Amsterdam and Philadephia: John Benjamins. https://doi.org/10.1075/sibil.9.09fre

Freed, B. (1998). An overview of issues and research in language learning in a study abroad setting. Frontiers: The Interdisciplinary Journal of Study Abroad, 4(2), 31-60. https://doi.org/10.36366/ frontiers.v4i1.62

Kinginger, C. (2008). Language learning in study abroad: case studies of Americans in France. The Modern Language Journal, 92, 1-124. https://doi.org/10.1111/j.1540-4781.2008.00821.x
Maxwell, J. A. (2012). Qualitative Research Design: An Interactive Approach. Thousand Oaks, CA: Sage. Retrieved from http://www.sagepub .com/upm-data/43454_10.pdf

Pellegrino, V. A. (1998). Student perspectives on language learning in a study abroad context. Frontiers: The Interdisciplinary Journal of Study Abroad, 4(2), 91-120. https://doi.org/10.36366/frontiers.v4i1.64

Rivers, W. P. (1998). Is being there enough? The effects of homestay placements on language gain during study abroad. Foreign Language Annals, 31(4), 492-500. https://doi.org/10.1111/j.1944-9720.1998 .tb00594.x

Tanaka, K., \& Ellis, R. (2003). Study abroad, language proficiency and learner beliefs about language learning. Japan Association for Language Teaching, 25(1), 63-84. https://doi.org/10.37546/ JALTJJ25.1-3

Wilkinson, S. (1998). On the nature of immersion during study abroad: some participant perspectives. Frontiers: The Interdisciplinary Journal of Study Abroad, 4(2), 121-138. https://doi.org/10.36366/ frontiers.v4i1.65

Wilkinson, S. (1998). Study abroad from the participant's perspective: a challenge to common belief. Foreign Language Annals, 31(1), 23-39. https://doi.org/10.1111/j.1944-9720.1998.tb01330.x 